Article

\title{
Carbon Footprint Estimation in a University Campus: Evaluation and Insights
}

\author{
Pablo Yañez ${ }^{1}$, Arijit Sinha ${ }^{2}$ and Marcia Vásquez ${ }^{3, *}$ \\ 1 Department of Community Engagement, Vice-Presidency of Outreach and Engagement, University of Talca, \\ 346000 Talca, Chile; payanez@utalca.cl \\ 2 Department of Wood Science and Engineering, College of Forestry, Oregon State University, Corvallis, \\ OR 97330, USA; Arijit.Sinha@oregonstate.edu \\ 3 Department of Environmental Forest Management, Faculty of Forestry Sciences, University of Talca, \\ 346000 Talca, Chile \\ * Correspondence: mvasquez@utalca.cl; Tel.: +56-994-586-715
}

Received: 3 October 2019; Accepted: 20 December 2019; Published: 24 December 2019

\begin{abstract}
Background: The University of Talca (UT), since 2012, has been annually tracking the carbon footprint (CF) based on the Greenhouse Gas (GHG) Protocol for all its five campuses. The purpose of this paper is to illustrate the trajectory for determining the $\mathrm{CF}$ on campuses and identify the stressors. Methods: GHG protocol separates emissions into three scopes-1) direct; 2) indirect; 3) other indirect emissions. This study reports the emissions on the Talca campuses that are related to Scopes 1 through 3. The data is closely studied to draw inferences on the factors most affecting $\mathrm{CF}$ and recommend improvements. Results: The estimation of the CF in Scope 1 and Scope 2 were $20.03 \mathrm{tCO}_{2} \mathrm{e}$ and 0.25 $\mathrm{tCO}_{2} \mathrm{e}$ per person per year, respectively. Results show Scope 3, which measures indirect emissions generated by activities like transportation of people, produced the highest contribution of $0.41 \mathrm{tCO}_{2} \mathrm{e}$ per person to the UT's CF in 2016. Conclusions: The study strongly suggested that transportation of students and faculty to and from the campus is one of the main stressors. The study of the main campus of Talca to quantify the CF is of immense value to institutions of higher educations as it provides a guideline and a comparative metric for other institutions.
\end{abstract}

Keywords: carbon footprint; corporation; scopes; GHG Protocol

\section{Introduction}

Over the last decade, sustainability reporting has gained importance in both profit and nonprofit organizations. Sustainability reporting provides information to decision-makers and acts as a catalyst for organizational change. Additionally, the International Association of Universities has made sustainable development in higher education one of its priorities [1]. The United Nations' report Our Common Future shows the multilateralism and interdependence of nations in the search for a sustainable path [2], or people's continuous efforts to attain a sustainable society. In the same way, the Sustainable Development Goals (SDGs) developed by the United Nations General Assembly in 2015 provide clear guidelines and targets for all countries to adopt in accordance with their own priorities and the environmental challenges of the world at large. Goal 13 of the SDGs specifically focuses on the need to address the issue of climate change. To combat the negative impacts of climate change, Goal 13 includes five targets, one of which is raising institutions' and humans' awareness on mitigating climate change, as well as enhancing their ability to do so [3]. The setting of goals and objectives under the aegis of the SDGs is an affirmative step to better educate the younger generation about sustainability and environmental impacts.

Common opinion holds that universities should be a beacon for society; they should be inclusive, honest, and sustainable, and encourage free speech and critical thinking. Consequently, universities 
have been regarded as institutions with significant responsibilities to help resolve issues of sustainability as well as serve as role models to society by implementing sustainable plans that entail monitoring the negative consequences of university operations [4]. Students in higher education should be educated on sustainable development and sustainable practices. The universities imparting education on sustainability should be concerned with their students' good practices and the impacts of their activities.

The Sustainable University initiative in Chile developed by Red Campus Sustentables [5] recognizes the importance of developing greener practices within university campuses, with the intent to engage students and staff in a constructive environmental dialogue. For more than a decade, the University of Talca (UT) has promoted its environmental policy, which establishes practices and improvements in relation to energy and water efficiency issues, waste, habitat protection and biodiversity, and the promotion of interdisciplinary research associated with sustainable development. One such institutional action has been measuring the carbon footprint (CF) within its different campuses since 2012 [6-9]. The historical evolution of CF measurements shows no clear patterns of reduction in some campuses that are explained in this paper. These measurements form part of the sustainable report that is annually disseminated to the university community at large. Authorities of the university are expecting that more people in the university community will get involved because they are inspired by the report to reduce its $C F$.

It is hard to establish a metric for sustainability efforts. There are many indicators to measure the effects of society's action on the environment. Ecological footprint (EF) is one of them. EF takes into account energy consumption, food consumption, waste disposal, water supply, transportation, and paper consumption [10]. EF estimates the "minimum land necessary to provide the basic energy and material flows required by the economy" [11]. However, different feeding habits of people make this measurement complex, and the chosen unit for the UTalca calculation is per person. Additionally, ISO started developing an international standard ISO 14064 on Carbon Footprint of Products and it is already a proposal to measure the CF of organizations. Similarly, the World Business Council for Sustainable Development (WBCSD) and the World Resources Institute (WRI) develop two standards under their Greenhouse Gas Protocol Product/Supply Chain Initiative: A Product Life Cycle Accounting and Reporting Standard: Guidelines for Value Chain (Scope 3) Accounting and Reporting [12]. In order to assess the environmental impact and report the sustainability of the university campus, this paper uses the CF based on the last initiative. CF is a concept created as a reference to see how viable the current consumption of fossil energies (oil, gas, coal) is and how it will be projected into the future [13]. In the following table (Table 1), selected important studies about CF of Universities are summarized with their methodologies and indicators. Table 1 is not an exhaustive list of studies on universities rather a selected set of studies chosen after an intensive literature review.

Table 1. Studies of carbon footprint (CF) measured in universities.

\begin{tabular}{|c|c|c|c|c|c|}
\hline Author & Year & Country & Method & Results & Highlights \\
\hline $\begin{array}{c}\text { Lo-lacono, et al. } \\
{[14]}\end{array}$ & 2018 & Spain & ISO 14064 & $\begin{array}{c}0.31 \mathrm{tCO}_{2} \mathrm{e} \text { per student } \\
2.69 \mathrm{tCO}_{2} \mathrm{e} \text { per } \\
\text { employee }\end{array}$ & $\begin{array}{c}\text { Polytechnic University of Valencia } \\
\text { considering } 3 \text { campuses. Measurement } \\
\text { consider only scope } 1 \text { and } 2\end{array}$ \\
\hline $\begin{array}{c}\text { Güereca et al. } \\
{[15]}\end{array}$ & 2013 & Mexico & $\begin{array}{l}\text { Greenhouse } \\
\text { Gas (GHG) } \\
\text { Protocol }\end{array}$ & $1.46 \mathrm{tCO}_{2} \mathrm{e}$ per person & $\begin{array}{l}\text { National Autonomous University of } \\
\text { Mexico. The measurement was focused } \\
\text { in the Engineering Institute. }\end{array}$ \\
\hline $\begin{array}{l}\text { Cited by } \\
\text { Vásquez et al. } \\
{[16]}\end{array}$ & 2015 & $\begin{array}{l}\text { Countries: } \\
\text { Spain, México, } \\
\text { USA, Norway }\end{array}$ & GHG Protocol & $\begin{array}{c}\text { Average of } 3.1 \mathrm{tCO}_{2} \mathrm{e} \\
\text { per student }\end{array}$ & $\begin{array}{l}\text { University of Madrid (Faculty of } \\
\text { Forestry), Autonomous University of } \\
\text { Mexico, Minnesota State University of } \\
\text { Mankato, Duquesne University and } \\
\text { Norwegian University of Science and } \\
\text { Technology. }\end{array}$ \\
\hline
\end{tabular}


Table 1. Cont.

\begin{tabular}{|c|c|c|c|c|c|}
\hline Author & Year & Country & Method & Results & Highlights \\
\hline Li et al. [17] & 2015 & China & $\begin{array}{l}\text { Novel } \\
\text { methodology } \\
\text { based on } \\
\text { survey }\end{array}$ & $3.84 \mathrm{tCO}_{2} \mathrm{e}$ per person & $\begin{array}{l}\text { Tongji University, Shanghai. } \\
\text { Methodology includes only GHG } \\
\text { emissions that can be linked directly to } \\
\text { students' activities. They call this study } \\
\text { as a personal carbon footprint because it } \\
\text { truncates the system to the reasonable } \\
\text { agency of a student. }\end{array}$ \\
\hline Letete et al. [18] & 2011 & South Africa & $\begin{array}{c}\text { Adapted GHG } \\
\text { protocol }\end{array}$ & $4.0 \mathrm{tCO}_{2}$ e per student & $\begin{array}{c}\text { University of Cape Town } \\
3.2 \mathrm{t} \mathrm{CO}_{2} \mathrm{e} \text { per student is related to energy } \\
\text { consumption }(80 \%)\end{array}$ \\
\hline $\begin{array}{l}\text { Larsen, et. al. } \\
\text { [19] }\end{array}$ & 2013 & Norway & $\begin{array}{c}\text { GHG } \\
\text { protocol/EEIO }\end{array}$ & $\begin{array}{c}4.6 \mathrm{tCO}_{2} \mathrm{e} \text { per student } \\
16.7 \mathrm{tCO}_{2} \mathrm{e} \text { per } \\
\text { employee }\end{array}$ & $\begin{array}{l}\text { Norwegian University of Science and } \\
\text { Technology. } \\
\text { Financial criteria focus on Scope } 3\end{array}$ \\
\hline \multirow{4}{*}{$\begin{array}{l}\text { Cited by } \\
\text { Almudafi and } \\
\text { Irfan [20] }\end{array}$} & \multirow{4}{*}{2016} & \multirow{4}{*}{ USA } & \multirow{4}{*}{ GHG Protocol } & $7.9 \mathrm{tCO}_{2} \mathrm{e}$ per student & University of Delaware \\
\hline & & & & $13.1 \mathrm{tCO}_{2} \mathrm{e}$ per student & University of Pennsylvania \\
\hline & & & & $24.6 \mathrm{tCO}_{2} \mathrm{e}$ per student & Yale University \\
\hline & & & & $36.4 \mathrm{tCO}_{2} \mathrm{e}$ per student & Massachusetts Institute of Technology \\
\hline
\end{tabular}

These previous studies (listed in Table 1) show that ISO 14064 and the Greenhouse Gas (GHG) protocol are the main methodologies to measure $\mathrm{CF}$ in universities. Given the nuances in the protocol, along with units of measurement, and the assumption trail included in each study, the results of such analyses will be disparate. Moreover, studies do not have a unique indicator to show their results and are usually expressed in $\mathrm{tCO}_{2} \mathrm{e}$ per student/employee/person. Considering all people who inhabit campuses as source of emission, this study shows their results per person.

The main objective of this study is to quantify the CF at the Talca campus of the University of Talca in Chile by comparing its measurements to historical data of the University of Talca's other four campuses: Curicó, Santiago, Colchagua, and Linares. In addition, the criteria used during the protocol implementation is evaluated in this study.

The Sustainable University Initiative promotes actions based on data recorded following CF results. Considering $\mathrm{CF}$ as an environmental management tool, data collected during the process allows a broader point of view on environmental performance of campuses, facilitating decision making. The results of this study will be useful to other universities worldwide, especially those in South American countries with similar economic, cultural, and geographic conditions as Chile.

\section{Materials and Methods}

In this section, the following topics will be addressed: (1) description of place of study, (2) explanation of the GHG Protocol as a research methodology and justification for using it, and (3) explanation of direct and indirect emissions produced on campus due to academic activities.

\subsection{Conditions at the Talca Campus of the University of Talca}

The University of Talca in Chile is one of the twenty-five institutions of higher education that make up the President's Council of Chilean Universities (CRUCH, Spanish acronym). Founded in 1981, it has progressively become one of the main national references for public, nonprofit higher education. The university's activities are informed by a strategic plan, to be in force until 2020, that includes the macro trends of the environment and, based on them, takes advantage of the opportunities to concretize the corporate vision of "Being recognized as a public, innovative, complex university of excellence; a reference in the higher education system and relevant in its development with the endeavors of the Country and the Region" [21].

The University of Talca has five satellite campuses located in the cities of Talca, Curicó, Linares, Colchagua, and Santiago. Together, these campuses have around 10,000 students enrolled in 19 undergraduate and 34 graduate programs. The largest campus in the University of Talca system is 
located in the city of Talca, the capital of the Maule Region. This region has a Mediterranean climate that imposes seasonal characteristics due to its annual precipitation: six months of rain from April to September and six months with a scarcity of rain from October to March [22].

During the study period of 2016, according to the university administration's data, the Talca campus had nine faculties (Health Science, Agronomical Science, Engineering, Economy and Business, Forest Science, Law and Social Science, Psychology, Architecture, Music, and Design), six institutes (Biological Science, Mathematics and Physics, Education R\&D, Chemical and Natural Resources, Humanistic Studies, Innovation based on Science), four main education departments (Academic, Innovation and Technological Transfer, Undergraduate, Student Development), and 10 technological centers (Bioinformatic and Molecular Simulation, Geomatic, Research and Transfer in Irrigation and Agroclimatology, Genetic Improvement and Plant Phenomena, Pomaceous, Vine and Wine, Soil and Cultivations, Poplar, Environmental Hydrology, Native Plants), with a population of 6941 students (mainly undergraduates) and staff of 928 people including faculty, staff, and other contracted personnel (guards, janitorial, food and maintenance services). The Talca campus consists of 55 buildings spread over 100 hectares, with a total constructed area of 98,000 square meters, including faculties, technological centers, classrooms, laboratories, library, gymnasium, food services, and administrative offices. The Talca campus is by far the largest in terms of area and enrollment.

This study does not include facilities located in Talca's downtown area, such as the institution's main office and extension center. By design, the study includes data from 2016 and compares it against data collected since 2012 in various campuses of UT. This provides a snapshot of five years in time. A similar study will be conducted after the next five years to compare and contrast the $\mathrm{CF}$ trends and will be reported as part of a future publication.

\subsection{GHG Protocol}

The University of Talca has been measuring its CF since 2012 with the objective of quantifying the greenhouse gases produced by the institution. This environmental management tool allows developing measures to reduce the environmental impact of the activities carried out on the campus. It started in one of the satellite campuses in Curicó. Then, year by year, more campuses were added and the Corporate Report of Sustainability of 2017 included the entire quantification of the CF of all UT campuses in 2016.

The Greenhouse Gas (GHG) Protocol of the World Resources Institute (WRI) and the World Business Council for Sustainable Development (WBCSD), published in 2011, gives requirements for quantifying GHG emissions within organizations under the Kyoto Protocol [23]. CF measure the greenhouse gas emissions that are directly or indirectly caused by an activity or are accumulated over the life stages of a product or service, expressed in carbon dioxide equivalents. According to the Intergovernmental Panel on Climate Change (IPCC) [24], there are 18 greenhouse gases with different global warming potential, but under the United Nations Framework Convention on Climate Change (UNFCCC) [25] and its Kyoto Protocol, only Carbon dioxide $\left(\mathrm{CO}_{2}\right)$, Methane (CH4), Nitrous Oxide (N2O), Hydrofluorocarbons (HFCs), Perfluorocarbons (PFCs), and Sulfur hexafluoride (SF6) are considered for the carbon accounting. GHG protocol is used to calculate $\mathrm{CF}$ as it is used by the University in the study as it is a part of the Sustainable Universities Initiative in Chile, which follows ISO guidelines and mandates using GHG protocol.

The five main objectives of this standard and guidance are: help companies prepare a GHG inventory that represents a true and fair account of their emissions through the use of standardized approaches and principles; simplify and reduce the cost of compiling a GHG inventory; provide businesses with information that can be used to build an effective strategy to manage and reduce GHG emissions; provide information that facilitates participation in voluntary and mandatory GHG programs; and increase consistency and transparency in GHG accounting and reporting among various companies and GHG programs. This protocol is widely recognized and used by the American College and University Presidents' Climate Commitment [26]. 
The GHG Protocol separates emissions into three scopes. Scope 1, direct emissions, includes those emissions from sources owned or controlled by the organization; Scope 2, indirect emissions, covers emissions from the organization's purchased electricity consumption; and Scope 3, other indirect emissions, includes emissions that result from activities within the organization, but from sources that are not owned or controlled by it [23].

\subsection{Direct and Indirect Emissions Evaluated in this Study}

This section reports the emissions generated by activities on the Talca campus that are related to Scopes 1 to 3 of the GHG Protocol standard, as well as the sources of data used for their calculation.

To establish the base of the study, the operational control that quantified GHG emissions where the organization can develop or apply management politics, was used to define the scope of inputs [27,28].

The following steps were used in order to determine the GHG emissions related to each category:

1. Determine the energy consumption in each category, such as kWh of electric consumption and liters of liquefied petroleum gas (LPG) consumption.

2. Find the updated GHG emissions factor associated with each category, such as $\mathrm{kgCO}_{2} \mathrm{e} / \mathrm{m} 3$, $\mathrm{tCO}_{2} \mathrm{e} / \mathrm{kWh}, \mathrm{kgCO}_{2} \mathrm{e} / \mathrm{km}$ traveled

3. Calculate amount of $\mathrm{CO}_{2} \mathrm{e}$ in each category by multiplying consumption per emission factor associated with each category.

A simple expression to reflect in the arithmetic term CF calculation is the following:

$$
C F\left(t \mathrm{CO}_{2} e\right)=\sum_{i=1}^{n}(\mathrm{Xi} \times \mathrm{Fi})
$$

where, $\mathrm{Xi}$ and Fi are the amount of energy (LPG, diesel, and electricity) and GHG emission factor per type of energy, respectively. Each campus was collecting the data to calculate the consumption of energy per year. Faculties, institutes, education departments and technological centers, administrative office, and student facilities, such as classrooms, laboratories, libraries, gymnasium and food services, were providing the data requested by the community engagement department. The GHG emission factors were obtained by different sources of well-recognized institutions that are explained ahead in Table 2.

The emissions evaluated in this study are the following:

\subsubsection{Direct Emissions of Scope 1}

In this study, Scope 1 covers direct emissions from fuel consumption of liquefied petroleum gas used on campus for heating and fuel for on-site transportation (security staff) and off-site transportation by car (paperwork or personnel) and institutional buses (student field trips or practices). This does not include student, staff, and faculty commutes to and from campus. The data was provided by the manager of campus administration for fuel consumed during 2016. The emission factor was obtained from the GHG Emission Inventory from the Chilean Ministry of Energy [29].

Fugitive emissions that leak from air conditioners using R-410 and R-22 refrigerants were also estimated by the manager of campus administration. Refrigerant emission calculations were carried out based on DEFRA (Department for Environment, Food, and Rural Affairs-Gov. UK) [27].

\subsubsection{Indirect Emissions of Scope 2}

Scope 2 covers indirect emissions by generation and transmission of electricity. Emissions are derived from the acquisition and consumption of energy in the organization but physically produced outside the boundaries of the organization.

The emission factor from 2016 was obtained from the Emission Inventory for the Central Interconnected System of the Chilean Ministry of Energy [29]. 
Table 2. Updated Greenhouse Gas (GHG) emission factors used to estimate the $\mathrm{CO}_{2} \mathrm{e}$ emissions and level of uncertainty of data collection by emission source.

\begin{tabular}{|c|c|c|c|c|c|}
\hline Used for & $\begin{array}{c}\text { Emission Source } \\
\text { and Unit }\end{array}$ & $\begin{array}{c}\text { Level of } \\
\text { Consumption }\end{array}$ & $\begin{array}{l}\text { Uncertainty } \\
\text { Level }\end{array}$ & $\begin{array}{l}\text { GHG Emission } \\
\text { Factor }\end{array}$ & Source \\
\hline $\begin{array}{l}\text { Cafeteria and dining } \\
\text { commons. Boilers } \\
\text { and powered } \\
\text { generator }\end{array}$ & LPG (1) & 101,323 & Medium & $1642 \mathrm{~kg} \mathrm{CO} 2 \mathrm{e} / \mathrm{m} 3$ & $\begin{array}{l}\text { Minenergia, } \\
2017 .\end{array}$ \\
\hline Institutional vehicles & Diesel Gasoline (1) & $26,390.71$ & Medium & $\begin{array}{l}2676 \mathrm{~kg} \mathrm{CO}_{2} \mathrm{e} / \mathrm{m} 3 \\
2241 \mathrm{~kg} \mathrm{CO} 2 \mathrm{e} / \mathrm{m} 3\end{array}$ & $\begin{array}{l}\text { Minenergia, } \\
2017 .\end{array}$ \\
\hline $\begin{array}{l}\text { Air conditioner } \\
\text { refrigerant }\end{array}$ & $\mathrm{R}-22(\mathrm{~kg})$ & 15.6 & Medium & $1810 \mathrm{~kg} \mathrm{CO}_{2} \mathrm{e} / \mathrm{kg}$ & DEFRA, 2016. \\
\hline $\begin{array}{l}\text { Air conditioner } \\
\text { refrigerant }\end{array}$ & $\mathrm{R}-410$ (kg) & 3.9 & Medium & $2088 \mathrm{~kg} \mathrm{CO}{ }_{2} \mathrm{e} / \mathrm{kg}$ & MMA, 2016. \\
\hline Electric system & Grid electricity (kwh) & $4,993,239$ & Low & 0.3972 t $\mathrm{CO}_{2} \mathrm{e} / \mathrm{MWh}$ & $\begin{array}{l}\text { Minenergia, } \\
2017 .\end{array}$ \\
\hline Staff trips & $\begin{array}{c}\text { Air travel. Short } \\
\text { haul, less than } 785 \\
(\mathrm{~km})\end{array}$ & 360 & Medium & $\begin{array}{c}0.17271 \mathrm{Kg} \\
\mathrm{CO}_{2} \mathrm{e} / \text { passenger km }\end{array}$ & DEFRA, 2012 \\
\hline Staff trips & $\begin{array}{l}\text { Air travel. Medium } \\
\text { haul, } 785-3700(\mathrm{~km})\end{array}$ & 87,408 & Medium & $\begin{array}{c}0.09695 \mathrm{Kg} \\
\mathrm{CO}_{2} \mathrm{e} / \text { passenger km }\end{array}$ & DEFRA, 2012 \\
\hline Staff trips & $\begin{array}{l}\text { Air travel. Long haul, } \\
\text { more than } 3700(\mathrm{~km})\end{array}$ & $3,458,480$ & Medium & $\begin{array}{c}0.0874 \mathrm{Kg} \\
\mathrm{CO}_{2} \mathrm{e} / \text { passenger km } \\
\end{array}$ & DEFRA, 2012 \\
\hline Printing & Paper consumption & $13,406.1$ & Medium & $0.939 \mathrm{~kg} \mathrm{CO}_{2} \mathrm{e} / \mathrm{kg}$ & DEFRA, 2016 \\
\hline Commute & Average bus (km) & $12,580,800.48$ & Low & $0.02867 \mathrm{~kg} \mathrm{CO}{ }_{2} \mathrm{e} / \mathrm{km}$ & DEFRA, 2016 \\
\hline Commute & Average car (km) & $8,354,610.54$ & Low & $0.18307 \mathrm{~kg} \mathrm{CO} 2 \mathrm{e} / \mathrm{km}$ & DEFRA, 2016 \\
\hline Commute & $\begin{array}{l}\text { Average local bus } \\
\qquad(\mathrm{km})\end{array}$ & $6,118,513.31$ & Low & $0.10172 \mathrm{~kg} \mathrm{CO} 2 \mathrm{e} / \mathrm{km}$ & DEFRA, 2016 \\
\hline Commute & Average van (km) & $989,851.6$ & Low & $0.2298 \mathrm{~kg} \mathrm{CO}{ }_{2} \mathrm{e} / \mathrm{km}$ & DEFRA, 2016 \\
\hline Commute & $\begin{array}{l}\text { Average motorcycle } \\
\qquad(\mathrm{km})\end{array}$ & $108,555.17$ & Low & $0.10642 \mathrm{~kg} \mathrm{CO} \mathrm{CO}_{2} \mathrm{e} / \mathrm{km}$ & DEFRA, 2016 \\
\hline Waste to landfill & Waste (kg) & 192,720 & Medium & $0.421 \mathrm{~kg} \mathrm{CO}_{2} \mathrm{e} / \mathrm{kg}$ & $\begin{array}{l}\text { HuellaChile, } \\
\text { MMA } 2017 .\end{array}$ \\
\hline Waste to recycling & Recycling (kg) & $20,356.5$ & Medium & $0.400 \mathrm{~kg} \mathrm{CO} 2 \mathrm{e} / \mathrm{kg}$ & DEFRA, 2016 \\
\hline
\end{tabular}

\subsubsection{Other Indirect Emissions of Scope 3}

Scope 3 covers other indirect emissions. This scope, according to most of the references for the calculation of an organization's CF, is an optional category that allows researchers to include indirect emissions not included in the previous scopes. Scope 3 activities are a consequence of activities of the organization that occur in locations or from sources that are not owned or controlled by the university.

To decide which emission sources are relevant for inclusion in this scope, it is possible to use the following criteria:

- Significance of the emissions with respect to the total emissions of the organization

- $\quad$ Representativeness of the activity in the organization as a whole

- $\quad$ Availability of auditable data

- Relevance for interested third parties (university community, civil society, administrations, suppliers, etc.)

- $\quad$ Potential for reducing emissions

It is possible to exclude emissions from sources whose contribution is not relevant (below the threshold of significance that the organization establishes) or if the calculation is technically or 
economically unfeasible. Some rules establish that those emission sources that contribute less than $1 \%$ to the total emissions can be excluded from the calculation.

In this scope, the study includes sources of emission that accomplish all the five criteria described above, such as student travel for field trips, air and land travel for academic staff, and staff and student commutes, paper and LPG consumption, and waste in landfill and recycling. Emission factors of paper consumption were taken from DEFRA database from United Kingdom [27]; fuel used in cars, buses, and vans; fuel used in airplane for short, medium, long flights, and recycling was taken from DEFRA database [27]; and waste from HuellaChile MMA, database from Chile [28]. Emissions sources that were not included in the 2016 CF measurement did not take into account the first four mentioned criteria. Due to this fact, the sources of emissions were toilet paper consumption and fuel consumption used to transport items such as paper, LPG, and waste. These sources of emissions were mainly not included due to its low significance based on previous year emission measurements and due to lack of information that is usually provided by registration of third party (external services, such as food service, maintenance, and campus security).

The results are reported as $\mathrm{CO}_{2} \mathrm{e}$ per person that includes students, staff, and employees. The carbon dioxide emissions of Talca campus per person was calculated by dividing the total emissions from Scopes 1, 2, and 3, whose primary sources were fuel consumption, electricity consumption, and commute, by the number of people. Similarly, the carbon dioxide emission of each scope per person was calculated by dividing each source of consumption (fuel, electricity, or commute) by the number of people.

\subsection{Exclusions and Assumptions}

Talca campus has two green areas: the Botanical Garden and the Arboretum. The total size of these two locations is 13 hectares. The mitigation of GHG based on absorption of carbon was not included in this study. Furthermore, the emissions produced in laboratories by chemical and physical processes were not calculated because they serve an academic purpose and are not part of the operation of the university.

Fugitive emissions from air conditioning were calculated with R-22 gas, which was not included initially in the calculations of the national database. The emission factor of this gas was taken from DEFRA [27].

Staff and student transportation data was collected using a survey, which was answered by $10 \%$ of students and staff at UTalca. Transportation distances for staff and students were estimated using digital maps and survey data. The sample size's behavior was assumed to be representative of the transportation pattern of the university's community at large.

\section{Results and Discussions}

\subsection{Analysis of the Current Situation of CF at the Talca Campus}

In this section, the total CF is analyzed. First, the total GHG emissions generated by each scope are presented for the Talca campus (Figure 1). Second, GHG emission factors for each source are reported in Table 2. Electricity mix is yearly updated, based on the source of energy of the Chilean grid. Third, the main emission sources and their associated activities for each scope are displayed. Fourth, the results are analyzed that relate to transport used for staff and student commutes, which are the largest source of emissions in Scope 3 (Table 2). Finally, the historical results of other campuses of the University of Talca are presented, subdivided by years (Figure 2) and participation of scopes (Figure 3).

It is important to take into account that not all campuses started CF measurement and reporting at the same time. This was implemented gradually due to the learning curve associated with the process. 

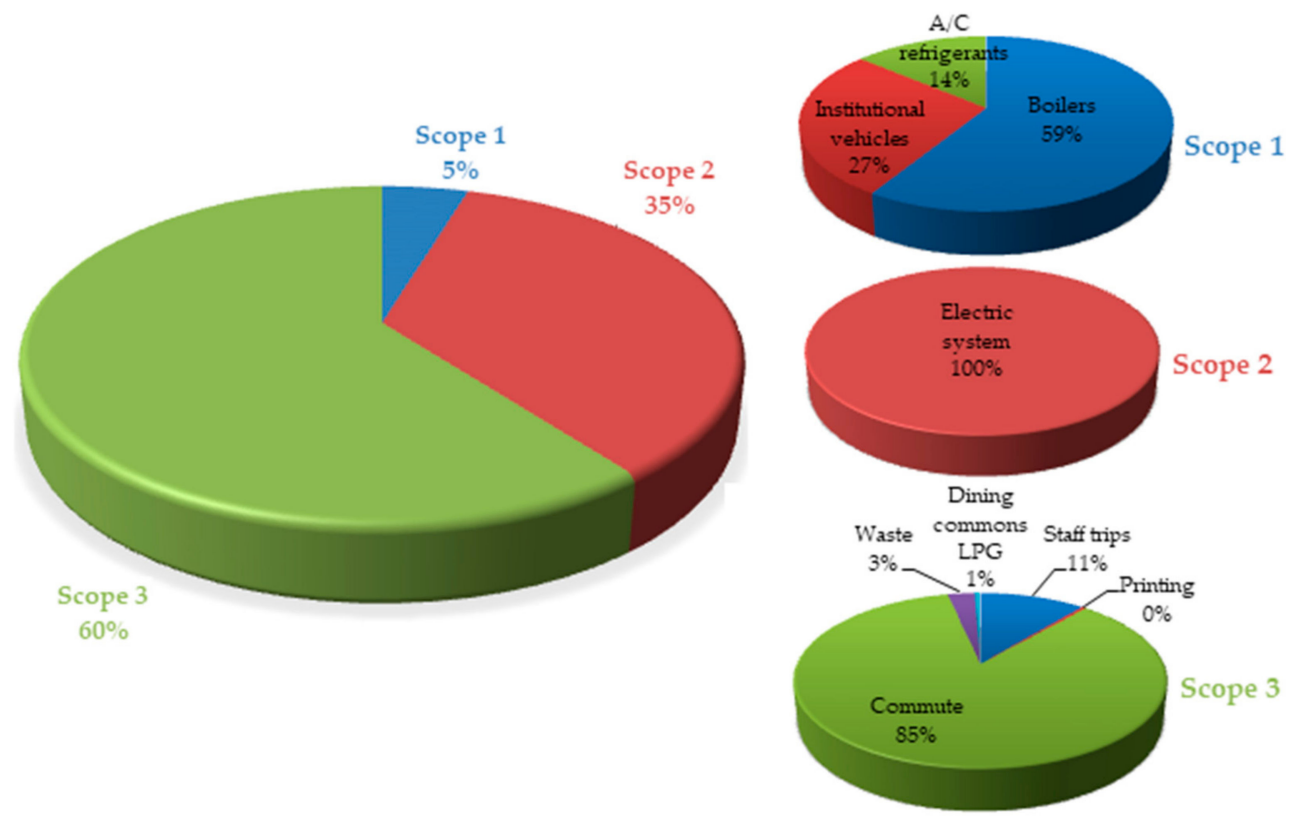

Figure 1. Carbon footprint (CF) by scope and sources at the Talca Campus. Note: Liquefied Petroleum Gas (LPG).

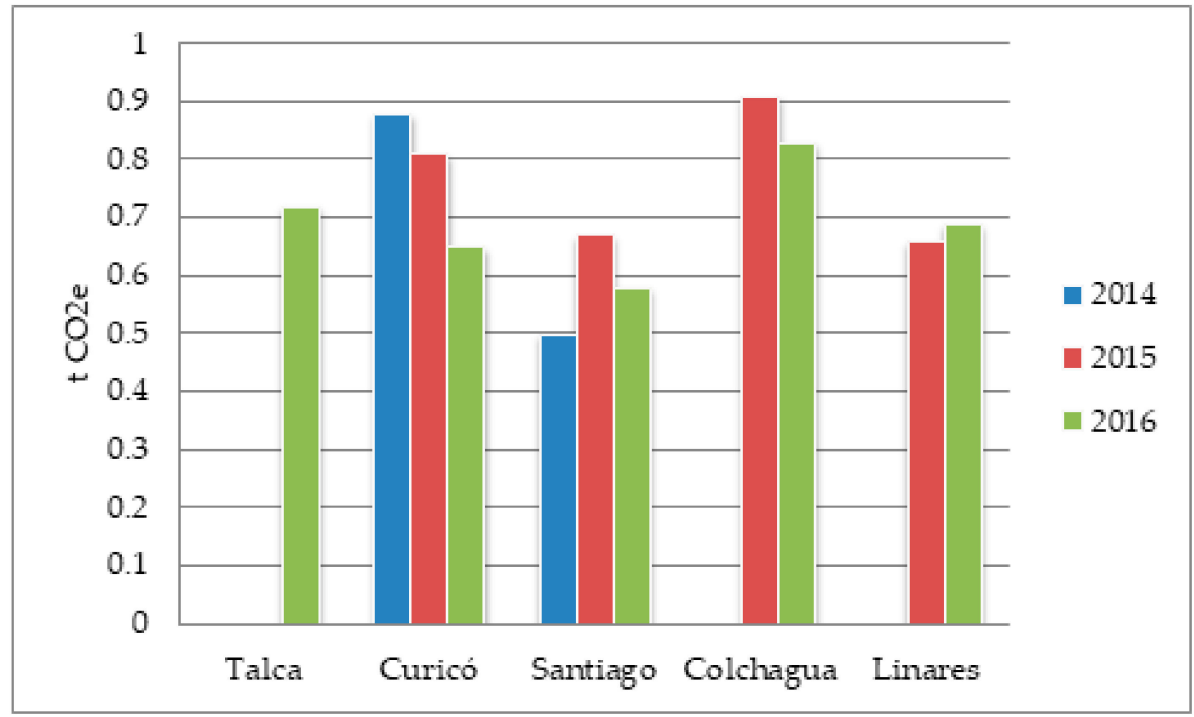

Figure 2. CF emission per person compared campuses by year. 


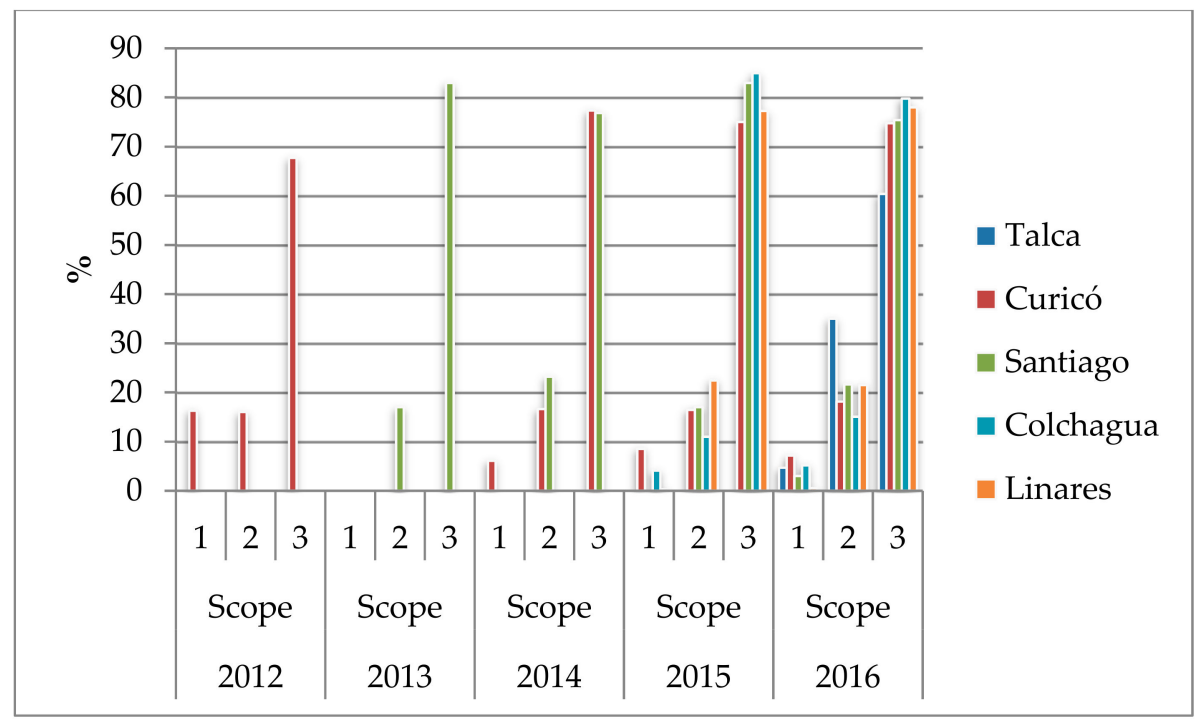

Figure 3. Historical $\mathrm{tCO}_{2} \mathrm{e}$ emissions for the University of Talca campuses subdivided by scope (\%).

\subsubsection{CF and Their Contribution per Sources and by Scopes}

The university's activities resulted in approximately 0.72 tons of carbon dioxide emissions per person in 2016. The CF reported is an assessment of the institution's emissions and is only a partial footprint because it does not take into account the full 24-h-day lifestyles of people within the colleges. It includes only the hours that they spend at the university each day and the commute time to get to campus [30]. The main contribution corresponds to Scope 3, followed by Scope 2, and then Scope 1. This suggests indirect emissions, rather than direct emissions, are significant contributors to the CF. These distributions are in agreement with Álvarez et al. [31]. However, according to the GHG Protocol, organizations must account for at least Scopes 1 and 2, emissions that can be controlled by the organization. In this case, Scopes 1 and 2 represent $40 \%$ of the total emissions of UTalca-Talca campus. Similar results were observed in Autonomous National University of Mexico and reported in Reference [15] (cited by [16]), where Scopes 1 and 2 accounted for $47 \%$ of the total emissions.

Table 2 shows the emissions factors, taking into account the calculations for all three scopes. Although the CF reported is for 2016, it includes some updated emission factors in 2017 due to general consensus among Chilean organizations.

The uncertainty in the data, as reported in Table 2, was associated with the way in which the data was collected and calculated. In this study, the level of uncertainty is adopted from the Program Huella Chile of the Ministry of Environment of Chile, which created a scale of uncertainty, based on the recommendations suggested by the Chilean standard ISO 14064 and the GHG Protocol [32]. In relation to the variability and updating of the emission factors, the grid electricity is a factor that is updated annually according to the gross generation, data delivered by the National Energy Commission of Chile; the rest of the emission factors have remained constant [29].

\subsubsection{Direct Emissions of Scope 1}

The estimation of the CF in Scope 1 is $264.28 \mathrm{t} \mathrm{CO}_{2} \mathrm{e}$ per year or $0.03 \mathrm{t} \mathrm{CO}_{2} \mathrm{e}$ per person per year. In our study, the main contributor to these emissions was LPG consumption in the boilers, which accounted for $147.47 \mathrm{t} \mathrm{CO}_{2} \mathrm{e}$. Other contributors were institutional vehicles $\left(72.39 \mathrm{t} \mathrm{CO}_{2} \mathrm{e}\right)$ and refrigerants $\left(36.38 \mathrm{t} \mathrm{CO}_{2} \mathrm{e}\right)$ and LPG consumption in powered generator $\left(8.04 \mathrm{t} \mathrm{CO}_{2} \mathrm{e}\right)$. GLP consumption from boilers was, however, the most dominant contributor in Scope 1. 


\subsubsection{Indirect Emissions of Scope 2}

Scope 2 presents a total of $1982.32 \mathrm{tCO}_{2} \mathrm{e}$ or $0.25 \mathrm{t} \mathrm{CO}_{2} \mathrm{e}$ per person per year, associated with the emission of GHG from the generation and transmission of electricity. Electricity generation accounted for $100 \%$ of the emissions associated with Scope 2. It is provided from the electric grid of the central interconnected system of Chile.

\subsubsection{Other Indirect Emissions of Scope 3}

A total of $3226.29 \mathrm{tCO}_{2} \mathrm{e}$ or $0.41 \mathrm{tCO}_{2} \mathrm{e}$ per person is caused by other indirect emissions that are produced mainly by daily transport of people moving on and off-campus in Talca $(85 \%$ as per Figure 1). Other inputs associated in this scope are: airplane business travels $\left(338.78 \mathrm{tCO}_{2} \mathrm{e}\right)$, waste production $\left(81.14 \mathrm{tCO}_{2} \mathrm{e}\right)$, vehicles business travels $\left(15.18 \mathrm{tCO}_{2} \mathrm{e}\right)$, paper consumption $\left(12.59 \mathrm{t} \mathrm{CO}_{2} \mathrm{e}\right)$, LPG consumption in dinner room, which is a third party service $\left(18.9 \mathrm{t} \mathrm{CO}_{2} \mathrm{e}\right)$, and recycling $(8.14 \mathrm{t}$ $\left.\mathrm{CO}_{2} \mathrm{e}\right)$.

Emissions in 2016, associated with commuting, are shown in Table 3. Although as a whole undergraduate student commute generate more emission, the per capita contribution to $\mathrm{tCO}_{2} \mathrm{e}$ is less than half of graduate students and roughly one fourth than staff (Table 3).

Table 3. Distribution of the means of transport used for staff and students commuting to the Talca Campus.

\begin{tabular}{cccc}
\hline & $\mathbf{t C O}_{\mathbf{2}} \mathbf{e}$ & Number of People & $\mathbf{t C O}_{\mathbf{2}} \mathbf{e}$ per Capita \\
\hline Undergraduate student commute & 1701.62 & 6715 & 0.25 \\
\hline Graduate student commute & 138.96 & 226 & 0.61 \\
\hline Staff commute & 910.99 & 928 & 0.98 \\
\hline
\end{tabular}

It is interesting to analyze people's behavior around transportation at the Talca campus. Locating residences around the institution reduced carbon emissions since students could walk or bike to campus. Increments of carbon emissions from graduate students and staff commuting (academics and non-academics) are attributed to their increased use of mechanized means.

Currently, public transportation in Chile does not use clean fuel from renewable sources. There are some examples of electric or compressed natural gas fueled cars in larger cities, but not in Talca, the region where the campus under analysis is located. People striving to reduce their environmental footprint might consider using public transportation with increased per capita energy efficiency. Therefore, awareness or incentive campaigns to encourage people to use public transportation will help reduce the footprint of transportation.

As observed in Table 1, the variability of data reported in similar studies could be explained by the methodology, and partial or total university analysis included in the database for the calculation of CF. Moreover, large discrepancies can be explained by the differences in student living habits at the different universities; most students in developed countries live on campus, commuting on foot, while students from developing countries live off-campus, community by car or bus.

\subsubsection{Historical CF of the University of Talca Campuses}

Measurements of CF from 2012 to 2016 in different campuses are shown in Table 4. CF measurement is a trend within the University of Talca system that began in 2012 as a pilot study in the Curicó campus, with 2016 being the first year in which all campuses reported their carbon emissions. Due to the lack of information about number of students and staff, it was not possible to create the indicator $\mathrm{CF} /$ person in 2012 and 2013. However, this information was recorded since 2014 and is presented in Figure 2. Local emission factors have been constantly improved due to advancements in research, greater awareness, and availability of additional data. Program Huella Chile MMA in 2013 is a prime 
example of an initiative of the Chilean government supporting the creation of local emission factors. Moreover, the total inputs used in Scope 3 have not varied since 2015. This context and agreements in the methodological framework produced less variability in the total results and allowed comparison of results among years.

Table 4. Historical CF of the University of Talca campuses, expressed in $\mathrm{tCO}_{2} \mathrm{e}$.

\begin{tabular}{cccccc}
\hline & $\mathbf{2 0 1 2}$ & $\mathbf{2 0 1 3}$ & $\mathbf{2 0 1 4}$ & $\mathbf{2 0 1 5}$ & $\mathbf{2 0 1 6}$ \\
\hline Talca & - & - & - & - & 5472.89 \\
\hline Curicó & 1568.5 & - & 1615.27 & 1505.83 & 1305.76 \\
\hline Santiago & - & 445.79 & 438.37 & 555.4 & 520.31 \\
\hline Colchagua & - & - & - & 212.66 & 194.89 \\
\hline Linares & - & - & - & 122.06 & 200.77 \\
\hline
\end{tabular}

Curicó and Santiago campuses had the longest period of CF measurement. The first case shows a continued reduction over time. Comparing this indicator in 2016 and 2014, a reduction of $26 \%$ is observed (Figure 2). This is attributed to several mitigating actions that were taken on this particular campus, such as replacing the original light bulbs with lower-energy, higher-efficiency bulbs, installing motion sensors for turning lights on and off in classrooms, and improving boiler efficiency, along with several others. Santiago case, the indicator of CF per person rises due to the effect of longer journeys in car and interurban buses done by commuting of postgraduate students who live outside the city. The Colchagua campus has the highest CF measured per person. This can be explained by the transport habits of the staff and student community, as well as the distances they travel. This observation reinforces the fact that indirect emissions of people and processes within the campus can be a major contributor to total impacts.

The Colchagua campus had the highest CF measured per person. This can be explained by the transportation habits of the staff and student community, as well as the distances they travel. This observation reinforces the fact that indirect emissions of people and processes within the campus can be a major contributor to total impacts.

A more exhaustive CF determination was developed in 2016 when the database of the Huella Chile Program was used, which was updated to represent the activities better at a national scale. Moreover, at the time many universities in Chile, including the University of Talca, were involved in an Agreement of Clean Production, where accounting for CF was mandatory. This fact guided the methodology and the decision regarding the choice of emission sources for analysis, particularly in Scope 3. The inputs considered are presented in Table 2. Although monitoring of CF had been going on since 2012, it was not until 2016 that CF for all campuses was calculated and reported. Therefore, this study looks into CF of 2016 in greater detail while the variation over time is presented and discussed (Figure 3).

According to Figure 3, across all campuses, the main contributor to CF is Scope 3. This source is difficult to control due to its execution by third parties. However, a university could control the quality of its suppliers, and the characteristics of the material used (local or external, renewable or nonrenewable, and durability, among others).

The effect of a university campus with satellite campuses is observed in Scope 3, where the Talca campus reports the lowest contribution due to the closeness of the students and workers to the organization. Historically, the contributions of Scope 3 in GHG emissions on the Curicó, Santiago, Colchagua, and Linares campuses were $75.7 \%, 78.92 \%, 82.34 \%$, and $77.62 \%$, respectively, compared with only $60.35 \%$ on the Talca campus. Distance traveled and transportation habits (car alone, shared car, public bus, biking, walking, taxi, or Uber, among others) are factors that can be studied and strategies can be formulated to reduce GHG emissions on campuses. This information can help guide policies to improve environmental protection and the life quality of the community. 


\subsection{Emission Reduction—General Discussion}

There are several ways the CF of campuses can be reduced. Stressors to the environment are analyzed using collected data. Additionally, ways to mitigate or reduce emissions are suggested.

The university can greatly benefit from applying an overarching energy management system to decrease the total energy consumption. This system will be implemented in 2020 in Talca campus. Adopting an energy management system such as ISO 50001 could result in a reduction of energy consumption of $6 \%$ [33]. This reduction in energy consumption translates into a $2.1 \%$ total GHG emission reduction. The university can further benefit from applying the overarching energy management system to decrease the total energy consumption. In the case of the Talca campus, adopting an energy management system such as ISO 50001 could result in a reduction of energy consumption of $6 \%$. This reduction in energy consumption translates into a $2.1 \%$ total GHG emission reduction.

Communal activities such as dining in the dining hall, studying in the library, and using public transportation should reduce the $\mathrm{CF}$. At the same time, creating a fully residential campus would reduce the transport component of the footprint described in Scope 3, which is the major contributor to CF. Since Scope 3 is the major stressor, there are several steps that can help reduce the reliance on mechanized transportation for commuting. The university can incentivize travel by public transportation such as buses and trains by providing to students and staff a subsidized commuter's pass. Furthermore, carpooling should be encouraged and perhaps rewarded with free or dedicated parking spaces. Traveling by bike should be encouraged.

An action that would complement those above is the accurate maintenance of boilers used on campuses, or retrofitting boilers to make them high efficiency, running on cleaner fuel. Technology is available but it needs substantial capital investment. Reference [34] found that the replacement of fossil fuels by renewable energy would lead to a reduction in the environmental footprint, cutting $\mathrm{CO}_{2}$ emissions by $17 \%$ if $23 \%$ of equipment were replaced. Similarly, a campus-wide move to fuel from renewable sources or cleaner fuels can significantly reduce CF. Nitkiewicz and Ociepa-Kubicka [35] analyzed the Life Cycle Assessment of different scenarios of biomass to produce energy in an organization, reported that an investment in a biomass-fired steam boiler that uses agricultural and woody biomass to produce energy showed a $25 \%$ decrease in the overall impacts.

Another way to reduce the $\mathrm{CF}$ is to offset it. This can be done by taking advantage of the sequestered carbon in the existing biomass and, if needed, planting new biomass. Incorporating the measurements of carbon absorption from the amount of biomass existing in the university's Arboretum and Botanical Garden (which cover a total of 13 hectares) and determining the capacity of annual carbon absorption by the annual increase of biomass are the major first steps. According to Ugle et al. [36], one ton of carbon storage in a tree represents the removal of $3.67 \mathrm{t}$ of carbon from the atmosphere and the release of $2.67 \mathrm{t}$ of oxygen back into the atmosphere. Similarly, some research has shown that carbon sink per hectare in the forest is important. For example, Liu [37] reported $33.22 \mathrm{t} / \mathrm{ha}$ of carbon stored by an urban forest in Shenyang, China; and Qasim [38] reported $44.64 \pm 12.44 \mathrm{t} / \mathrm{ha}$ in the trees from Azad Jammu and Kashmir Parks, India. Comparatively larger values of carbon are found in trees because of their large biomass.

Important data should be collected in botanical gardens, such as tree species, biodiversity, age, mean annual increment, among others, to estimate the reduction of GHG emissions. Carbon sequestration assessment requires uniform, standardized methodologies able to quantify the variability of key parameters that account for carbon sequestration. Additionally, the carbon stocks generated by afforestation, composed of relatively young forest patches, aged from 10 to 28 years, are not negligible. Many researchers report that trees can reach 1 ton per hectare per year and are predicted to double after 12 years ([39-42]).

The selection criteria of inputs in Scope 3 are very important. There are aspects of comparing measurements between campuses that are related to the quantities and types of inputs that are accounted for in the final results of the scope. For example, inputs related to transportation of LPG, toilet paper, and recycled waste could be left out of the calculation due to their low levels of contribution 
to the final results, simplifying the process of data collection. A similar situation occurs with fuel consumption in outsourced services that represents information not controlled by the organization and whose contribution has been evaluated as marginal. These examples describe irrelevant emission sources that could be omitted.

Finally, a greater effort toward educating members of the community about their contribution to the CF level would raise awareness of the issue and could be expected to go a long way toward reducing CF levels. This action will reduce GHG emissions related to all scopes.

\section{Conclusions}

The empiric evidence about methodologies to calculate CF in institutions of higher education shows that there is more than one way to calculate it. However, the GHG protocol is a widely recognized and well-known methodology to calculate CF. Additionally, it is important to develop emissions inventory based on case studies. In this study of CF at the University of Talca, Scope 3 emission sources like commuting, paper consumption, LPG consumption, waste generation, water consumption, and business travels were deemed important because of its institutional relevance and contribution to the total emissions and, therefore, must be quantified.

The analysis of the evolution that the measurement of the CF had during 2012-2016 provides in methodological terms and identification of the GHG emission inventory, a clear and concise vision on the way in which to perform the measurement of CF in the next years. The development of sustainable campuses in the world and its relationship with the management of greenhouse gases aims at carbon neutrality. In this sense, understanding the complexities existing in each campus from the consolidation of its GHG emission inventories to the way of collecting data is key aspect to develop strategies that seek to reduce and neutralize emissions.

The study strongly suggested that the transportation of students and faculty to and from the campus is one of the main stressors. Another activity contributing significantly to CF was the operation of boilers. The CF of a university depends, among other factors, on the technologies or good practices adopted in facility management to be more efficient with resources, mainly in climatization, use of paper and waste generation. Some universities contain energy-intensive facilities, which could increase one of the scopes of this indicator. In addition, the types of automobiles used in commutes directly affect the scope 3. Regardless, promoting and incentivizing public transportation, shared commuting, and bicycling can help reduce the CF.

Indirect impact, associated with scope 3, which is currently optional in GHG protocol, was the single largest contributor to CF on all campuses. Consequently, a framework must be defined for adding indirect emission sources and the choice of their inputs, ensuring the accomplishment of the criteria of emission source selection. Moreover, it is important to strengthen the effort to build the foundations of local emission inventories adapted to the reality of each measurement. Accounting carbon emissions and reporting them acts as a reflection of due diligence and can serve several purposes including formulating efforts in order to reduce emissions.

Author Contributions: Conceptualization, P.Y., A.S., and M.V.; methodology, P.Y. and M.V.; software, P.Y.; validation, P.Y. and M.V.; formal analysis, P.Y., A.S., and M.V.; investigation, P.Y. and M.V.; resources, P.Y. and M.V.; data curation, P.Y.; writing-original draft preparation, P.Y. and M.V.; writing-review and editing, A.S.; visualization, M.V.; supervision, M.V.; project administration, P.Y.; funding acquisition, P.Y. All authors have read and agreed to the published version of the manuscript.

Funding: This research was funded by the Department of Community Engagement at the University of Talca.

Acknowledgments: The authors would like to thank the data collection work done by Carolina Vidal, Nathalia Valenzuela, and Ricardo Cáceres, undergraduate students of Forestry Engineering at the University of Talca. Furthermore, we thank the Community Engagement Department for financial support and all Directors, assistances, professors, students, and people who provided the data for this study.

Conflicts of Interest: The authors declare no conflict of interest. 


\section{References}

1. Land, H.V.T.; Herzog, F. Higher Education Paving the Way to Sustainable Development: A Global Perspective; International Association of Universities (IUA): Paris, France, 2016.

2. Brundtland, G.H. Report of the Worl Commission on Environmemt and Development. Our Common Future; United Nations: Oslo, Norway, 1987.

3. NU-CMCC. Informe de la Conferencia de las Partes sobre su 21er periodo de sesiones, celebrado en París del 30 de noviembre al 13 de diciembre de 2015. In Proceedings of the 2015 United Nations Climate Change Conference, Paris, France, 30 November-12 December 2015.

4. Adenle, $\mathrm{Y}$; Alshuwaikhat, $\mathrm{H}$. Spatial estimation and visualization of $\mathrm{CO}_{2}$ emissions for campus sustainability: The case of King Abdullah University of Science and Technology (KAUST), Saudi Arabia. Sustainability 2017, 9, 15. [CrossRef]

5. Red Campus Sustentable. Memoria 2018. Red Campus Sustentable; Red Campus Sustentable: Santiago, Chile, 2019.

6. Universidad de Talca. Reporte de Sostenibilidad; Universidad de Talca: Maule, Chile, 2014.

7. Universidad de Talca. Reporte de Sostenibilidad; Universidad de Talca: Maule, Chile, 2015.

8. Universidad de Talca. Reporte de Sustentabilidad; Universidad de Talca: Maule, Chile, 2016.

9. Universidad de Talca. Reporte de Sustentabilidad; Universidad de Talca: Maule, Chile, 2017.

10. Li, G.J.; Wang, Q.; Gu, X.W.; Liu, J.X.; Ding, Y.; Liang, G.Y. Application of the componential methos for ecological footprint calculation of a Chinese university campus. Ecol. Indic. 2008, 8, 75-78. [CrossRef]

11. Wackernagel, M.; Rees, W. Our Ecological Footprint: Reducing Human Impact on the Earth; New Society Publisher: Gabriola Island, BC, Canada, 1996.

12. Finkbeiner, M. Carbon footprinting-Opportunities and theats. Int. J. Life Cycle Assess. 2009, 14, 91-94. [CrossRef]

13. Baquedano, M. Tu Huella Ecológica, Calcula tu Huella de Carbono; Editorial Cuantro Vientos: Santiago, Chile, 2011.

14. Lo-Iacono, V.; Torregrosa, J.; Capuz, S. The use of carbon footprint as a key performance indicator in higher education institutions. In Proceedings of the 22nd International Congress on Project Management and Engineering, Madrid, Spain, 11-13 July 2018.

15. Güereca, L.P.; Torres, N.; Noyola, A. Carbon footprint as a basis for a cleaner research institute in Mexico. J. Clean. Prod. 2013, 47, 396-403. [CrossRef]

16. Vásquez, L.; Iriarte, A.; Almeida, M.; Villalobos, P. Evaluation of greenhouse gas emissions and proposals for their reduction at a university campus in Chile. J. Clean. Prod. 2015. [CrossRef]

17. Li, X.; Tan, H.; Raches, A. Carbon footprint analysis of student behavior for a sustainable university campus in China. J. Clean. Prod. 2015, 106, 97-108. [CrossRef]

18. Letete, T.; Wandile, N.; Guma, M.; Marquard, A. Carbon footprint of the University of Cape Town. J. Energy South. Afr. 2011, 22, 2-12. [CrossRef]

19. Larsen, H.; Pettersen, J.; Solli, C.; Hertwich, E. Investigating the Carbon Footprint of a University-The case of NTNU. J. Clean. Prod. 2013, 48,39-47. [CrossRef]

20. Almufadi, F.; Irfan, M. Initial estimate of the carbon footprint of Qassim University, Saudi Arabia. Int. J. Appl. Eng. Res. 2016, 11, 8511-8514.

21. Universidad de Talca. History University of Talca. Available online: www.utalca.cl/english/html/histoty/ history.html (accessed on 22 April 2017).

22. Universidad de Talca. Características Agroclimáticas de Talca. CITRA (Centro de Investigación y Transferencia en Riego y Agroclimatología). Available online: www.citrautalca.cl/html/agroclimatología/características_ agroclimáticas_talca.html (accessed on 2 October 2017).

23. WRI and WBCSD. Greenhouse Gas Protocol. World Resources Institute. Available online: www.ghgprotocol. org (accessed on 15 March 2017).

24. Intergovernmental Panel on Climate Change. Climate Change: The IPCC Scientific Assessment; Cambridge University Press: Cambridge, UK, 1990.

25. United Nations Framework Convention on Climate Change. The Kyoto Protocol to the Convention on Climate Change; UNFCCC Secretariat: Bonn, Germany, 1997. 
26. Sinha, P.; Schew, W.; Sawant, A.; Kolwaite, K.; Strode, S. Greenhouse gas emissions from U.S. institutions of higher education. J. Air Waste Manag. Assoc. 2010, 60, 568-573. [CrossRef] [PubMed]

27. Department for Environment, Food and Rural Affairs. Calculation Methodology for the Carbón Calculator; Department for Environment Food \& Rural Affairs: London, UK, 2014.

28. MMA. Desarrollo de Factores de Emisión Específicos para el Programa HuellaChile. Ministerio del Medio Ambiente. Available online: http://huellachile.mma.gob.cl (accessed on 15 June 2017).

29. Minenergía. Emisiones de Gases de Efecto Invernadero (GEI) por Energía Generada en Sistemas Eléctricos. Ministerio de Energía de Chile. Available online: www.minenergia.cl/indicadoresambientales/?page_id=105 (accessed on 15 June 2017).

30. Dawe, G.; Vetter, A.; Martin, S. An overview of ecological footprint and other tolos and their application to the development of sustainability process: Audit and methodology at Holme Lacy College, UK. Int. J. Sustain. High. Educ. 2004, 5, 340-371. [CrossRef]

31. Álvarez, S.; Blanquer, M.; Rubio, A. Carbon footprint using the compound method based on financial accounts. The case of the School of Forestry Engineering, Technical University of Madrid. J. Clean. Prod. 2014, 66, 224-232. [CrossRef]

32. MMA. Manual de Usuario. Herramienta de Cálculo de Gases de Efecto Invernadero Organizacional; Huella, P., Ed.; Ministerio del Medio Ambiente: Santiago, Chile, 2016; p. 31.

33. Roda Energy. A Chilean consultant of energetic engineering. Available online: www.rodaenergia.cl (accessed on 13 April 2018).

34. Carpio, M.; Martín-Morales, M.; Zamorano, M. Environmental and economic effects of using renewable energy in residential termal installations according to 2030 targets: Case study in the Province of Granada (Spain). Constr. Technol. 2018, 93, 474-477. [CrossRef]

35. Nitkiewicz, T.; Ociepa-Kubicka, A. Eco-investments-Life Cycle Assessment of different scenarios of biomass combustion. Ecol. Chem. Eng. S. 2018, 25, 307-322. [CrossRef]

36. Ugle, P.; Rao, S.; Ramachandra, T.V. Carbon sequestration potential of urban tres. In Proceedings of the Lake 2010: Wetlands, Biodiversity and Climate Change Conference, Bengaluru, India, 22-24 December 2010.

37. Liu, C.; Li, X. Carbon storage and sequestration by urban forest in Shenyang, China. Urban. For. Urban. Green. 2012, 11, 121-128. [CrossRef]

38. Qasim, M. Forest carbón stock assessment of the Musk Deer National Park, Azad Jammu and Kashmir (AJK). J. Trop. For. Environ. 2017, 7, 122-127. [CrossRef]

39. Brown, S. Measuring carbón in forests: Current status and future challenges. Environ. Pollut. 2002, 116, 353-372. [CrossRef]

40. Nowak, D.; Crane, D. Carbon storage and sequestration by urban trees in the USA. Environ. Pollut. 2002, 116, 381-389. [CrossRef]

41. Chen, Y.; Liu, Z.; Rao, X.; Liang, C.; Lin, Y.; Zhou, L.; Cai, X.; Fu, S. Carbon storage and allocation pattern in plant biomass among different forest plantation stands in Guangdong, China. Forests 2015, 6, 794-808. [CrossRef]

42. Agonafir, H.; Worku, M. Carbon stock in Gullele Botanical Garden: Implications for carbon emissions reduction, North Western Addis Ababa, Ethiopia. J. Environ. Earth Sci. 2017, 7, 40-52.

(C) 2019 by the authors. Licensee MDPI, Basel, Switzerland. This article is an open access article distributed under the terms and conditions of the Creative Commons Attribution (CC BY) license (http://creativecommons.org/licenses/by/4.0/). 